\title{
Survey examines the adoption of perceived best management practices for almond nutrition
}

\author{
by Sara E. Lopus, María Paz Santibáñez, Robert \\ H. Beede, Roger A. Duncan, John Edstrom, \\ Franz J. A. Niederholzer, Cary J. Trexler and \\ Patrick H. Brown
}

\section{Fertilizer use in California agricul-} ture has been under recent scrutiny regarding its impacts on air, surface water and groundwater quality. In June 2007, we surveyed almond growers to assess their plant nutrition practices, identify opportunities for improvement, and target research and extension needs. The majority of respondents, particularly those with large almond acreages, used fertigation to apply nitrogen; applied nitrogen coincident with periods of maximal plant demand; and collected annual tissue samples for analysis. While the survey results suggested broad compliance with the bestavailable management practices and are likely to indicate good nutrientuse efficiency, they also suggested that growers are uncertain about current practices to monitor orchard nutrient status and would value additional information to enable greater precision in fertilization rates and timing.

$\mathrm{N}$ itrogen $(\mathrm{N})$ is a key mineral element for the global food supply (Hirel et al. 2007; Vitousek et al. 1997), and adding nitrogen fertilizer is a fundamental step in producing commercially viable crops. However, nitrogen that is not taken up by plants or retained in soil organic matter will "leak" from agricultural systems, contributing to environmental challenges such as greenhouse-gas emissions in the form of nitrous oxide $\left(\mathrm{N}_{2} \mathrm{O}\right)$ (Veltholf et al. 2009) and watershed pollution in the form of high nitrate $\left(\mathrm{NO}_{3}\right)$

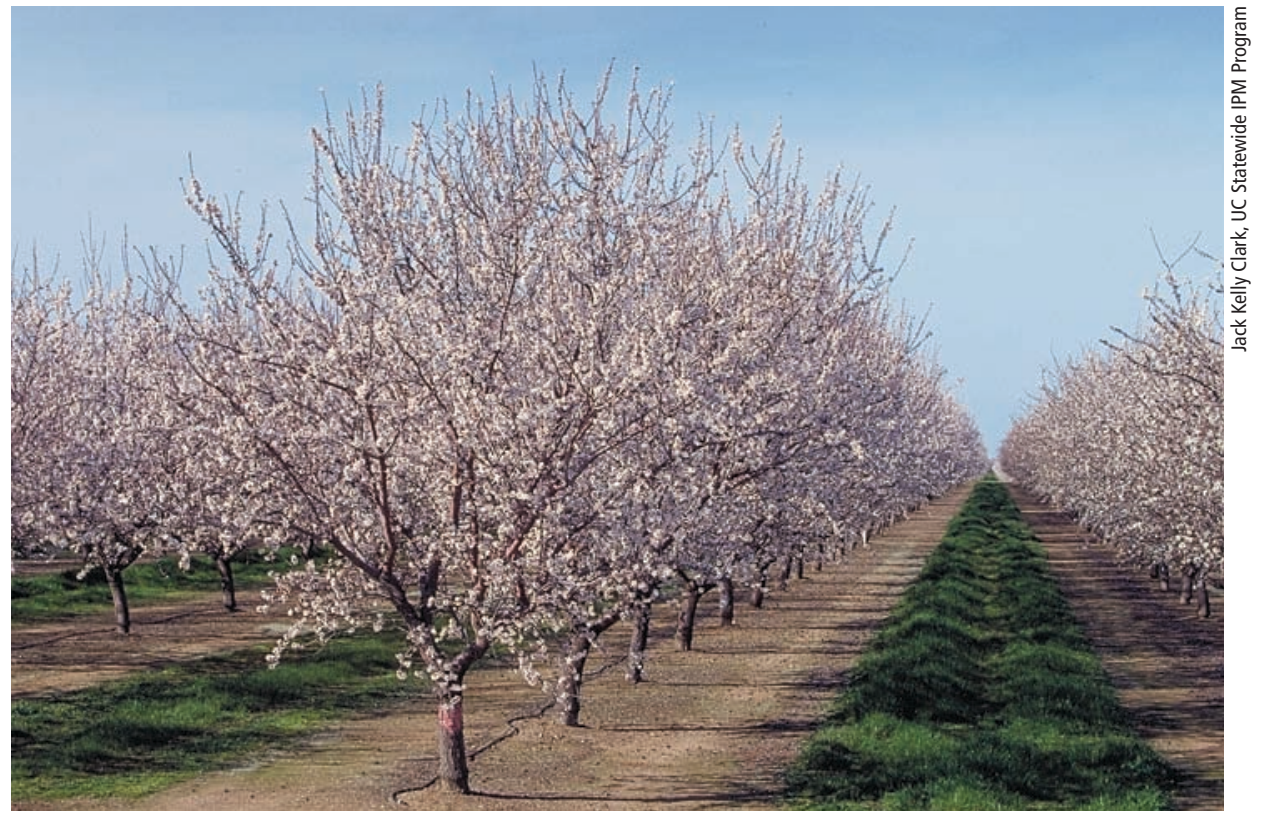

There are more than 6,000 almond growers in California and 615,000 bearing acres. Above, an almond orchard in bloom at Nickels Soil Laboratory in Colusa County.

concentrations in water (Domagalski et al. 2008).

In 2006, California legislators identified reducing greenhouse gases as a major goal and passed Assembly Bill 32 , which mandates that by 2020 , statewide emissions be reduced $25 \%$ from 1990 levels (CARB 2006). Industries utilizing nitrogen have attracted policymakers' attention for their potential greenhouse-gas reductions, because a single unit of nitrous oxide gas is equivalent in potency to approximately 300 units of carbon dioxide $\left(\mathrm{CO}_{2}\right)$ gas (IPCC 1995). In 2004, the California Air Resources Board concluded, based on the limited data available, that agricultural soils were the largest source of nitrous oxide in California, accounting for $50 \%$ of the state's total emissions, with $60 \%$ related to synthetic fertilizers (CARB 2006). Because of nitrous oxide's global warming potential, even modest reductions can contribute meaningfully to lowering greenhouse-gas emissions by 2020 .

Soil nitrate concentrations can increase significantly when applied and mineralized nitrogen levels exceed the plant's nitrogen use. Nitrate in runoff from heavily fertilized agricultural land can reach rivers and streams, raising concerns about drinking-water quality and the eutrophication of water bodies (Fenn et al. 1998), in which high nutrient levels in an aquatic ecosystem lead to increased primary production (by algae, for example) and subsequent decreases in oxygen levels.

Burow et al. (1998) found that a high proportion of groundwater samples from beneath almond orchards exceeded the maximum contaminant level of nitrate (10 milligrams per liter [mg/L]) (EPA 2006), reflecting high levels of nitrogen applications. Almonds represent California's fifth-largest agricultural commodity (in percentage of the state's total farm receipts) (USDA ERS 2009), and the industry has grown to more than 6,000 almond growers and 615,000 bearing acres (ABC 2008). Nitrogen management in almonds has been the subject of much research, and a summary of conventional practice is presented in the UC Almond Production Manual (Micke 1996).

Adding nitrogen to soil increases the potential for both nitrous oxide generation and nitrate leaching. To minimize 


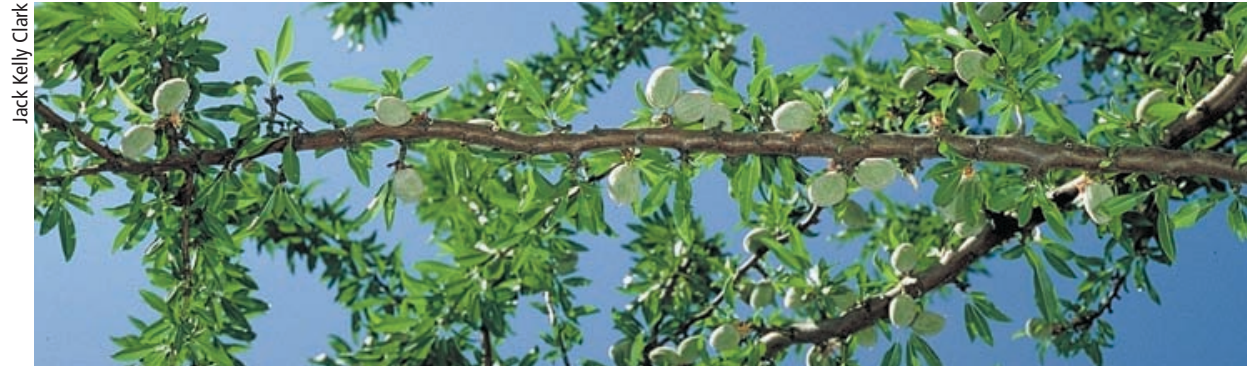

\section{Because of nitrous oxide's global warming potential, even modest reductions can contribute meaningfully to lowering greenhouse-gas emissions by 2020 .}

this potential, management practices that reduce total nitrogen inputs, increase the utilization of applied nitrogen by crops, and enhance nitrogen stability in soil must be developed and adopted. Bruulsema et al. (2008) summarized the principles and practices underlying the development of fertilizer best-management practices for nitrogen. These include: (1) the use of soil or plant testing to define crop nutrient status and (2) application of the right amount of fertilizer coincident with the times of greatest crop demand, placed in locations and forms that maximize uptake potential and minimize losses.

In agricultural systems where explicit experimental data and fertilization guidelines are poorly developed, fertilization practices that approach these ideal characteristics represent the best-available management practice and are most likely to optimize nitrogen-use efficiency. Given the absence of specific nutrition management guidelines for almonds, we theorize that these principles can best be applied under current production constraints through: (1) fertigation to enable nitrogen placement in the zone of greatest root activity, (2) the application of nitrogen coincident with periods of greatest nutrient demand and (3) tissue sampling and analysis to monitor nutrient levels in trees.

In June 2007, we surveyed almond growers to assess their current nutrition practices, concerns and needs. This article focuses on comparisons between respondent practices and the set of theorized best-management practices. We also present general demographic traits for respondents who did not adhere to the perceived best practices, in order to inform extension efforts related to nutrient-use efficiency.

\section{Survey design and analysis}

We designed and distributed a survey with 37 multipart questions to collect data regarding grower demographics (18 questions), fertilization-use practices (11 questions), factors affecting fertilization decisions (two questions), priorities in education and research relating to plant nutrition (three questions) and the expected consequences of environmental regulation to the almond industry (three questions). The questions were informed by the results of three concurrent focus-group sessions held in 2006 at the Almond Industry Conference in Modesto, Calif. Each consisted of 10 to 14 growers, chemical consultants, farm advisors and/or representatives from the California Environmental Protection Agency, California Air Resources Board and Almond Board of California (Lopus et al. 2010).

The survey population comprised 1,800 almond growers from 18 California counties, whose names were randomly selected from a pesticide-use database of 3,060 growers. Although we also surveyed all organic almond growers $(n=76)$ registered with California Certified Organic Farmers, the results are not presented in this article. In accordance with standard protocol (Dillman 2007), postcards were mailed in April 2007 to draw growers' attention to the forthcoming survey, surveys were mailed in June 2007, and second copies of the survey were mailed in August 2007 to growers who had not yet responded. Growers were given the option of submiting the survey by mail or online. Surveys were coded to maintain the anonymity of respondents and to ensure that online respondents were members of the randomly selected sample.

To assess fertilizer nitrogen use in almond orchards, we compared current grower practices with our set of theoretical best-management practices derived from existing knowledge, focus groups, e-mail consultations with informed individuals in the industry and the concepts in Bruulsema et al. (2008). Although many practices not discussed here have been applied in other cropping systems and may aid in achieving enhanced nitrogen-use efficiency, none have been adequately validated in almonds. Therefore, for this investigation we focused on three currently available practices for which grower compliance is measurable: (1) using fertigation to apply some or all nitrogen fertilizer in orchards (where irrigation methods permit), (2) applying nitrogen fertilizer with perceived optimal seasonality and (3) using annual tissue sampling to monitor nutrient levels in trees.

\section{Assessing nutrition practices}

We identified fertigation, in which fertilizer is applied through an orchard's irrigation system, as a theorized best-management practice because it allows for multiple in-season applications, targeted timing and synchrony with irrigation, potentially reducing fertilizer use and optimizing efficiency.

Optimized application timing ensures that nitrogen is available to trees when they are actively taking up nutrients. Research suggests that the pattern of nutrient demand during a cropping cycle closely matches the rate of nutrient accumulation in the almond crop, once nutrient reserves in perennial tissues have been depleted (Weinbaum et

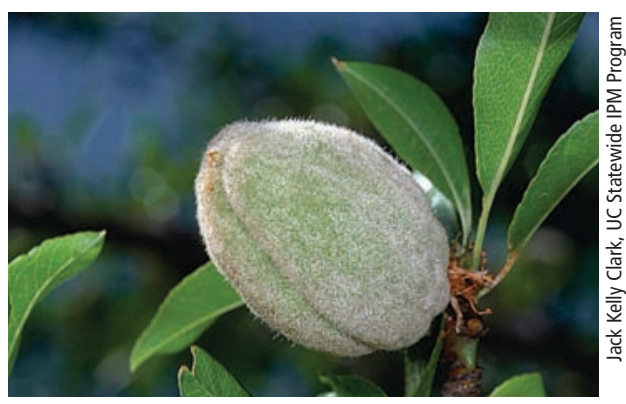


al. 1980, 1990). Under California conditions, nutrient uptake in almond trees commences following full leaf expansion in March or early April; increases during periods of rapid fruit development in late spring and summer; is maximal during nut filling and prior to full maturity; and declines once the fruit reaches full maturity, with minimal nutrient uptake occurring during leaf senescence or dormancy.

If growers are to make nutrients available to trees at optimal times, the most nutrient should be applied during summer, a smaller portion in spring and in autumn, and none in winter. For the seasonality analysis, we calculated each grower's deviation from this schedule of nutrient uptake. Scores ranged from 2 to 10, with 10 assigned to growers who applied with optimal seasonality and the lowest possible score of 2 assigned to those who applied $100 \%$ of nitrogen fertilizer in winter (see box, table 1).

In deciduous tree production, the primary tool for fertilizer decisionmaking is leaf sampling and analysis and comparison with established standards, called "critical values" (Brown and Uriu 1996). Critical values are the nutrient levels (present in almond tissues at a specific time of the cropping cycle each year) below which trees will begin to show deficiency symptoms. They represent the tipping point between a tree that is or is not deficient in a particular nutrient. When properly taken and analyzed, annual tissue samples provide growers with useful information about their trees' nutrient status and demand, allowing nitrogen applications to be adjusted accordingly.

Data was analyzed with chi-square analysis $(\alpha=0.05)$, and logistic regression was used for answers rated on a Likert scale. Response areas left blank and "I don't know" answers were excluded from the analysis. Data analysis was performed using JMP 7 statistical software (SAS 1989-2007).

Of the 1,800 growers that we mailed the survey to, 38 informed us that they no longer grow almonds and 529 completed the survey, for an overall response rate of $30.0 \%(529 / 1,762)$. Of the 529 respondents, seven grew some or all of their almonds organically, so we analyzed their responses separately; results

\section{Calculation of seasonal score}

In order to calculate seasonal scores, we awarded points to growers based on the percentage of nitrogen that they applied during each seasonal period: 0 points $=0 \% ; 1$ point $=1 \%$ to $30 \% ; 2$ points $=31 \%$ to $70 \% ; 3$ points $=71 \%$ to $99 \%$; and 4 points $=100 \%$.

Seasonal periods were defined as: winter, Nov. 1-Jan. 31; spring, Feb. 1April 30; summer, May 1-July 31; fall, Aug. 1-Oct. 31.

The scores for each season were then subtracted from the optimal scores and subtracted from 10 :

\section{Seasonal score $=$ \\ 10 - Ispring score - 1| - |summer score - 2| - |fall score - 1| - winter score}

For example, grower A applies $20 \%$ of nitrogen in spring, $65 \%$ in summer, $15 \%$ in fall and $0 \%$ in winter, and receives a seasonal score of 10 (table 1). We classified seasonal scores of 7 or greater as "good" and seasonal scores of 6 or below as "poor."

\begin{tabular}{|c|c|c|c|c|c|c|c|}
\hline & & Spring & Summer & Fall & Winter & $\begin{array}{l}\text { Dev. } \\
\text { from } \\
\text { optimal }\end{array}$ & $\begin{array}{l}\text { Seasonal score } \\
(10-\text { dev. })\end{array}$ \\
\hline "Optimal" & points & 1 & 2 & 1 & 0 & & \\
\hline \multirow{3}{*}{ Grower A } & Applied (\%) & 20 & 65 & 15 & 0 & & \\
\hline & Points & 1 & 2 & 1 & 0 & & \\
\hline & & $|1-1|=0$ & $|2-2|=0$ & $|1-1|=0$ & $|0-0|=0$ & 0 & 10 \\
\hline \multirow{3}{*}{ Grower B } & Applied (\%) & 35 & 25 & 25 & 15 & & \\
\hline & Points & 2 & 1 & 1 & 1 & & \\
\hline & & $|1-2|=1$ & $|2-1|=1$ & $|1-1|=0$ & $|0-1|=1$ & 3 & 7 \\
\hline \multirow{3}{*}{ Grower C } & Applied (\%) & 50 & 0 & 0 & 50 & & \\
\hline & Points & 2 & 0 & 0 & 2 & & \\
\hline & & $|1-2|=1$ & $|2-0|=2$ & $|1-0|=1$ & $|0-2|=2$ & 6 & 4 \\
\hline
\end{tabular}

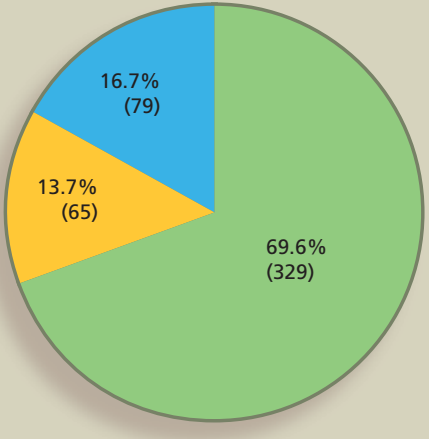

(A) Growers

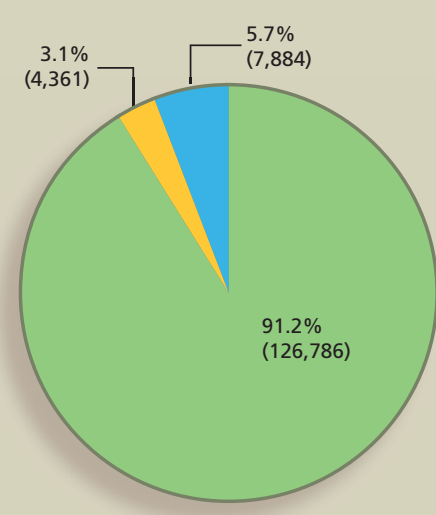

(B) Acres
Some or all $\mathrm{N}$ applied with fertigation $\quad$ Cannot use fertigation $\quad$ Can use fertigation, but do not

Fig. 1. (A) Growers and (B) acres with nitrogen fertilizer applied using fertigation. Those who cannot use fertigation irrigated entirely by flood or furrow. 
TABLE 2. Growers and acres performing theorized best-management practices

\begin{tabular}{|c|c|c|c|c|c|c|c|c|}
\hline & \multirow[b]{2}{*}{ All growers } & \multicolumn{3}{|c|}{ By generation growing almonds } & \multicolumn{4}{|c|}{ By acreage } \\
\hline & & First & $\geq$ Second & $P$ value & $<20$ & $20-249$ & $\geq 250$ & $P$ value \\
\hline & \multicolumn{4}{|c|}{$\ldots \ldots \ldots \ldots \ldots$ (number/n) $\ldots \ldots \ldots$} & \multicolumn{4}{|c|}{$\ldots \ldots \ldots \ldots \%$ (number/n) $\ldots \ldots \ldots$} \\
\hline Apply nitrogen with fertigation* & $80.6(329 / 408)$ & $81.3(135 / 156)$ & $72.4(126 / 174)$ & 0.051 & $61.2(30 / 49)$ & $63.8(136 / 189)$ & $94.1(96 / 102)$ & $<0.001$ \\
\hline High seasonal score & $65.0(294 / 452)$ & $58.0(130 / 224)$ & $71.9(161 / 224)$ & 0.002 & $57.1(48 / 84)$ & $63.3(167 / 264)$ & $77.2(61 / 79)$ & 0.008 \\
\hline $\begin{array}{l}\text { Collect tissue samples at least } \\
\text { once annually }\end{array}$ & $79.4(396 / 499)$ & $77.1(195 / 253)$ & $82.6(200 / 242)$ & 0.122 & $61.0(64 / 105)$ & $82.0(232 / 283)$ & $90.7(98 / 108)$ & $<0.001$ \\
\hline
\end{tabular}

of the organic population are not presented in this article. Thirty of the 529 responses $(5.7 \%)$ were submitted online.

By county, the respondents were representative of the whole population, as the selected recipients of each county were proportional to the whole population $\left(X^{2}=6.98, P=0.935\right)$.

\section{Best application practices}

Nitrogen fertigation. Most respondents (69.6\%) (fig. 1A) applied any or all of their nitrogen fertilizer by fertigation. Of the remaining $30.4 \%$ who did not use fertigation, $45.1 \%$ ( $13.7 \%$ of all respondents) were unable to fertigate because they irrigated entirely by flooding or furrow and could not inject fertilizer into the irrigation system. More than half of the growers (54.9\%) who did not use fertigation had the potential technical capacity to adopt the practice. A small portion (6.4\%; five of 78 ) of these growers used fertigation to apply potassium and/or zinc fertilizer, but not nitrogen.

Among growers with the technical capacity for fertigation (excluding those who irrigated entirely by flood and/or furrow), there was no significant difference $(P=0.051)$ in likelihood to fertigate between first-generation and secondgeneration or greater growers (table 2).

Among all growers with the technical capacity to fertigate, there was a significant relationship between likelihood to fertigate and acreage $(P<0.001)$ (table 2). Growers with fewer than 20 acres were less likely to use fertigation to apply nitrogen $(61.2 \%)$, while those with 250 or more acres were more likely to use fertigation (94.1\%). Due to this trend, the proportion of acres managed by a grower who practiced fertigation was higher than the proportion who used the practice (fig. 1B). Growers who

TABLE 3. Importance of information or actions to meet potential environmental standards, rated from 1 ("not important") through 5 ("extremely important")

\begin{tabular}{|c|c|c|c|}
\hline & Mean & SD & $n$ \\
\hline \multicolumn{4}{|l|}{ Information very or extremely important* } \\
\hline Identifying fertilization practices that optimize yields & 4.03 & 0.85 & 358 \\
\hline $\begin{array}{l}\text { Identifying fertilization practices that minimize soil and water } \\
\text { contamination }\end{array}$ & 3.66 & 0.92 & 367 \\
\hline Conducting research to challenge new requirements & 3.63 & 1.02 & 350 \\
\hline \multicolumn{4}{|l|}{ Information important, very or extremely important $t$} \\
\hline $\begin{array}{l}\text { Creating nutrient budgets that accurately reflect an orchard's } \\
\text { fertilizer needs }\end{array}$ & 3.47 & 0.85 & 357 \\
\hline Effectively regulating grower compliance & 2.81 & 0.94 & 350 \\
\hline
\end{tabular}

* Median score of 4. Number of responses ( $n$ ) varied by question because blank and "I don't know" responses were excluded. † Median score of 3. Number of responses ( $n$ ) varied by question because blank and "I don't know" responses were excluded.

managed $91.2 \%$ of almond acreage in the survey used fertigation to apply any or all nitrogen fertilizer (fig. 1B), and the adoption of fertigation by growers who did not currently use the practice but had the capability was only possible on $5.7 \%$ of acreage.

Seasonality. We classified seasonal scores of 7 or greater as "good" $(65.0 \%$ of respondents; mean $=7.13$, standard deviation $[\mathrm{SD}]=1.61$ ) and scores of 6 or below as "poor" (35.0\%) (table 2). Poor seasonal scores corresponded to growers whose seasonal fertilization practices differed dramatically from the optimal schedule (Weinbaum et al. 1980, 1990) (see box, page 151).

The distribution of seasonal scores between first-generation growers and others was significantly different $(P=0.002)$, with only $58.0 \%$ of first-generation growers having good seasonal scores versus $71.9 \%$ or secondgeneration or greater growers (table 2).

The distribution of seasonal scores differed significantly with acreage $(P=$ 0.008 ) (table 2). Growers with fewer than 20 acres were less likely to have good seasonal scores $(57.1 \%)$ than growers with 250 or more acres (77.2\%). Growers with poor seasonal scores managed only $23.5 \%$ of the acreage surveyed (28,021 of 199,422 acres).

Tissue sampling. Most respondents (79.4\%) used tissue sampling on their orchards at least once per year, and very few $(7.6 \%, 38$ of 499$)$ never used tissue sampling (table 2). Of growers who did not use tissue sampling at least once per year, $21.4 \%$ (22 of 103) collected tissue samples when problems were detected. Growers who collected tissue samples less than once per year cited the expense $(31.9 \%, 22$ of 69$)$ and difficulty in interpreting and/or using results $(15.9 \%, 11$ of 69$)$ as major reasons why they did not collect tissue samples more often.

There were no significant generational differences $(P=0.122)$ (table 2$)$ between first-generation growers and other growers in the likelihood to use tissue sampling at least once annually.

The distribution of likelihood to collect tissue samples at least once per year differed significantly with acreage $(P<0.001)$ (table 2). Growers with fewer than 20 acres were less likely to collect 
tissue samples at least once annually (61.0\%), while those with 250 or more acres were more likely (90.7\%). Only $10.6 \%$ of acres were managed by growers who did not collect tissue samples at least once per year.

Grower attitudes. Although 61.3\% of respondents stated that they were satisfied with their current nutrition management practices (315 of 514), only $29.5 \%$ (149 of 505) considered UC critical values (which dictate fertilization goals for particular nutrients) to be fully adequate to ensure maximal productivity. When rating the importance of five activities relating to potential environmental regulations, most growers identified three of the activities as very or extremely important (median rating of 4 or greater) (table 3$)$, including identifying fertilization practices that optimize yields. From a list of 14 potential research topics, most growers selected eight topics as very or extremely useful (table 4), including fertilizer application timing.

\section{Implications for outreach}

The trends revealed by the survey will be useful to extension agents as they create outreach programs to reduce nitrogen loss and increase efficiency in almond production. Firstgeneration almond growers, for example, were less likely to apply nitrogen with good seasonal timing (table 2), and almond growers with fewer than 20 acres were less likely to apply nitrogen with fertigation, apply nitrogen with good seasonal timing or collect annual tissue samples (table 2). It may therefore be effective to target firstgeneration and small almond growers with educational nutrition-management programs. The observation that small and/or first-generation growers are less likely to use the theorized best-nutrient practices may indicate that extension activities are not optimally tailored to these groups.

External factors such as the cost, availability and functionality of fertigation technologies for small growers may be significant constraints, suggesting that targeted financial incentives to develop or employ small-scale fertigation systems are needed to enhance the adoption of best nutrient practices. Since growers with large acreages are more likely to have adopted them, the perceived progressive practices of large growers dominate California almond acreage.

The practices investigated here represent our best current understanding of actions to achieve nitrogen-use efficiency (Bruulsema et al. 2008). Likewise, this survey did not attempt to identify whether growers fertigate properly, add appropriate amounts of nitrogen, or correctly use the results of tissue sample analyses to formulate their fertility programs. It therefore remains unclear if the use of best available practices is actually resulting in satisfactory efficacy of nitrogen use.
Even the most informed growers are uncertain about the practical applications of tissue analyses, since: (1) experimental trials examining the relationship between leaf tissue analysis and crop yield in almond are limited (Brown and Uriu 1996; Meyer 1996; Weinbaum et al. 1980, 1990); (2) no longterm experiments in mature trees have effectively demonstrated the use of leaf analysis to optimize fertilization regimes and nitrogen-use efficiency; and (3) it is difficult to obtain representative tissue samples in a perennial species due to substantial within-tree, between-tree and within-field variability (Lilleland and Brown 1943; Perica

TABLE 4. Usefulness of future UC research topics, from 1 ("not useful") through 5 ("extremely useful")*

\begin{tabular}{|c|c|c|c|}
\hline & Mean & SD & $n$ \\
\hline \multicolumn{4}{|l|}{ Topic very or extremely useful* } \\
\hline Fertilizer application timing & 3.90 & 0.90 & 345 \\
\hline Leaf-sampling techniques that better reflect tree nutrient demand & 3.83 & 0.95 & 352 \\
\hline Relationship between nutrition and disease & 3.81 & 0.89 & 349 \\
\hline Accuracy of critical values to ensure they result in maximal yield & 3.79 & 0.89 & 349 \\
\hline Tissue-sampling techniques that better reflect tree nutrient demand & 3.76 & 1.01 & 339 \\
\hline Role and optimal use of foliar fertilizers & 3.71 & 0.97 & 340 \\
\hline Relationship between fertilization and irrigation & 3.65 & 0.99 & 353 \\
\hline Nutrient management in problem soils & 3.57 & 1.11 & 337 \\
\hline Interactions between nutrients & 3.55 & 0.93 & 340 \\
\hline \multicolumn{4}{|l|}{ Topic useful, very or extremely usefult } \\
\hline Fertilization practices to optimize orchard establishment & 3.46 & 0.95 & 340 \\
\hline Precision agriculture (site-specific fertilization) & 3.20 & 1.06 & 339 \\
\hline Optimal use of fertigation systems & 3.20 & 1.20 & 336 \\
\hline Effectiveness of nonfertilizer foliar and soil products & 2.78 & 1.13 & 348 \\
\hline Remote sensing and automated nutrient status measurement & 2.67 & 1.12 & 349 \\
\hline
\end{tabular}

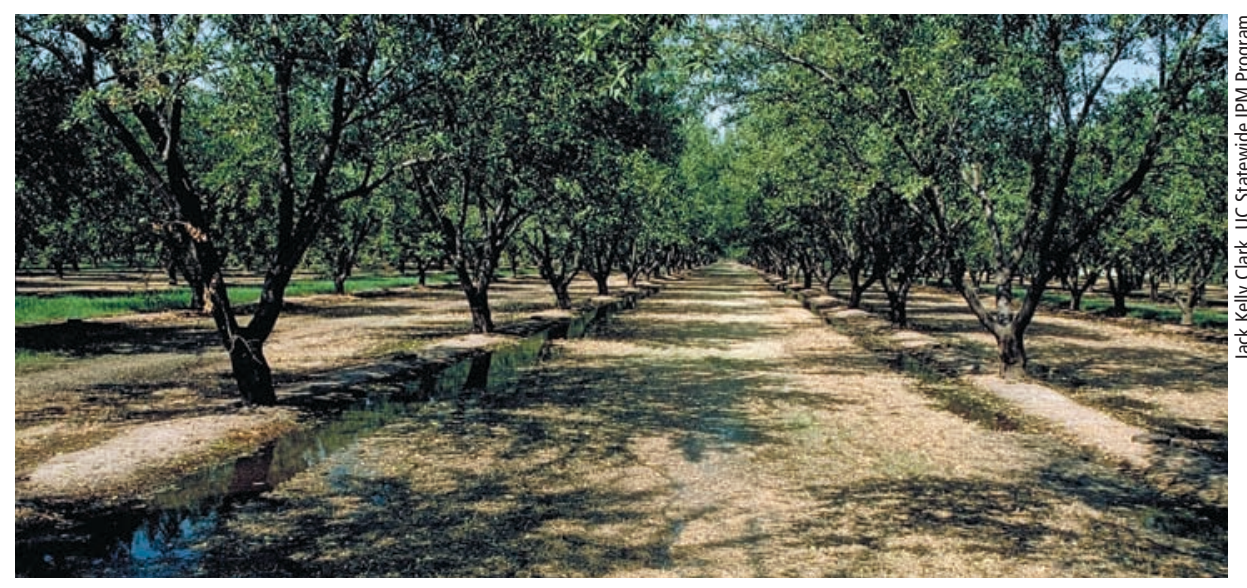

Best management practices including fertigation, timed applications and leaf-tissue analysis can save growers money and minimize nutrient-laden runoff into surface waters. Above, furrowirrigated orchards cannot use fertigation, which requires a drip irrigation system. 
2001; Righetti et al. 1990; Sanchez and Righetti 1990).

In this paper, we addressed only three management practices believed to contribute to nitrogen-use efficiency; there are many other practices, however, that can theoretically contribute to nitrogen efficiency in the almond industry and for which research-based understanding is inadequate. These other practices include, but are not limited to: (1) soil sampling, (2) selecting proper nitrogen forms given seasonal timing and the crop stage, (3) determining nitrogen rates by tree age, potential yields and past yields and (4) balancing the leaf levels of other nutrients to gain the maximum benefits of applied nitrogen. These practices are not widely used in California's almond industry, so compliance was not investigated.

The creation of nitrous oxide and nitrate is unavoidable in agricultural settings and will occur on even the best-managed land. Almond productivity cannot be maintained in the absence of fertilization, so any nitrogen

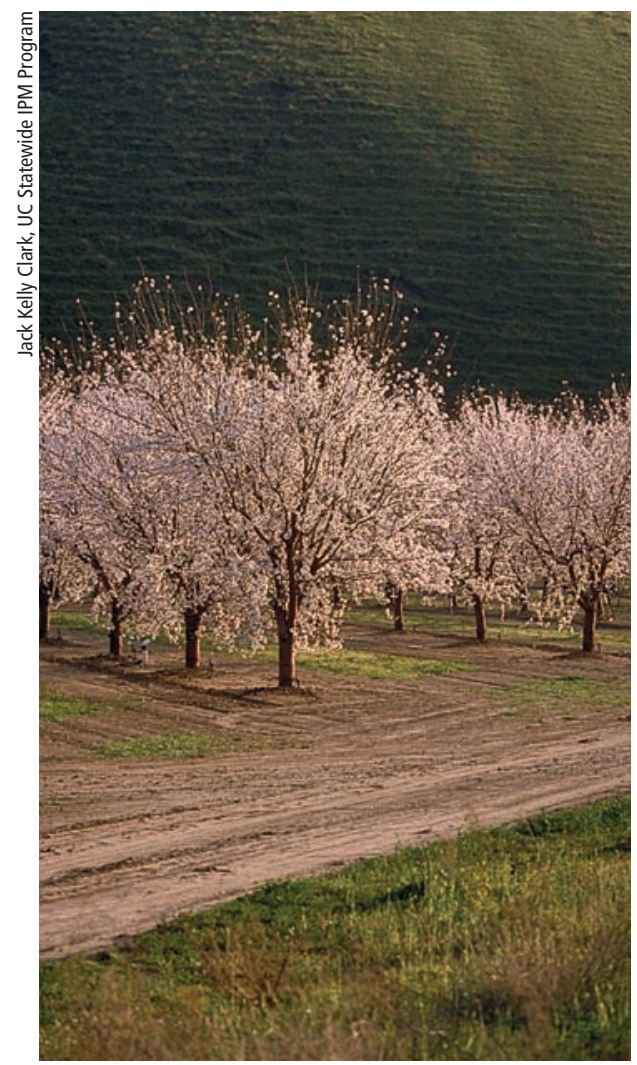

The survey found that most almond growers, managing the large majority of California acreage, currently employ best practices for nitrogen fertilization. Above, an orchard in Stanislaus County. mitigation program must focus on increasing the efficiency with which applied nitrogen is used. The results of this survey illustrate that most almond growers, and the large majority of acreage, currently employ theorized bestfertilization practices, and the industry would value new information about a wide breadth of topics relating to nutrition management. While these results can be viewed as largely positive, they should be the basis for deploying new research and extension programs to develop integrated best management of nutrients in almonds and address the actions and research topics that growers identified as highly important.

\section{References}

[ABC] Almond Board of California. 2008. 2008 Almond Almanac. Modesto, CA. p 1-46.

Brown PH, Uriu K. 1996. Nutrition deficiencies and toxicities: Diagnosing and correcting imbalances. In: Micke W (ed.). Almond Production Manual. UC ANR Pub 3364. p 179-88.

Bruulsema TW, Witt C, Garcia F, et al. 2008. A global framework for fertilizer BMPs. Better Crops Plant Food 92:4-6.

Burow KR, Shelton JL, Dubrovsky NM. 1998. OCcurrence of nitrate and pesticides in ground water beneath three agricultural land-use settings in the eastern San Joaquin Valley, California, 1993-1995. US Geological Survey Water-Resources Investigations Report 97-4284.

[CARB] California Air Resource Board. 2006. Assembly Bill No. 32. www.leginfo.ca.gov/pub/05-06/bill/ asm/ab_0001-0050/ab_32_bill_20060927_chaptered. pdf.

Dillman DA. 2007. Mail and Internet Surveys: The Tailored Design Method (2nd ed.). Hoboken, NJ: J Wiley. 480 p.

Domagalski JL, Ator S, Coupe R, et al. 2008. Comparative study of transport processes of nitrogen, phosphorus and herbicides to streams in five agricultural basins, USA. J Environ Qual 37:1158-69.

[EPA] US Environmental Protection Agency. 2006. Consumer Factsheet on Nitrates/Nitrites. Washington, DC. www.epa.gov/ogwdw/contaminants/ dw_contamfs/nitrates.html.

Fenn ME, Poth N, Aber JD, et al. 1998. Nitrogen excess in North American ecosystems: Predisposing factors, ecosystem responses and management strategies. Ecol Appl 8(3):706-33.

Hirel B, Le Gouis J, Ney B, Gallais A. 2007. The challenge of improving nitrogen use efficiency in crop plants: Towards a more central role for genetic variability and quantitative genetics within integrated approaches. J Exp Bot, Nitrogen Nutrition Special Issue 58(9):2369-87.

[IPCC] Intergovernmental Panel on Climate Change. 1995. IPCC second assessment synthesis of scientific technical information relevant to interpreting Article 2 of the UNFCCC. Geneva, Switz. p 64.
S.E. Lopus was M.S. Student, Department of Plant Sciences, UC Davis, and is now Ph.D. Student, Department of Demography, UC Berkeley; M.P. Santibáñez was M.S. Student, Department of Plant Sciences, UC Davis; R.H. Beede is Farm Advisor, UC Cooperative Extension (UCCE), Kings County; R.A. Duncan is Farm Advisor, UCCE Stanislaus County; J. Edstrom is Farm Advisor, UCCE Colusa County; F.J.A. Niederholzer is Farm Advisor, UCCE Sutter and Yuba Counties; C.J. Trexler is Associate Professor, School of Education and College of Agricultural and Environmental Sciences, UC Davis; and P.H. Brown is Professor, Department of Plant Sciences, UC Davis. We are grateful to the Almond Board of California and the California Department of Food and Agriculture for funding this research project.

Lilleland O, Brown JG. 1943. Phosphate nutrition of fruit trees. Proc Amer Soc Hort Sci 41:1-10.

Lopus SE, Trexler CJ, Grieshop JI, Brown PH. 2010 Using focus groups to assess almond growers' plant nutrition information needs. Renewable Agric Food Syst. In press.

Meyer RD. 1996. Potassium fertilization/foliar N/P/K/B studies. Years of Discovery (1972-2003). Almond Board of California, Modesto, CA. p 291-2.

Micke W (ed.). 1996. Almond Production Manual. UC ANR Pub 3364. p 294

Perica S. 2001. Seasonal fluctuation and intracanopy variation in leaf nitrogen level in olive. J Plant Nutr 24:779-87.

Righetti TL, Wilder KL, Cummings GA. 1990. Plant analysis as an aid in fertilizing orchards. In: Westerman RL (ed.). Soil Testing and Plant Analysis. Soil Science Society of America, Madison, WI. p 563-601.

Sanchez EE, Righetti TL. 1990. Tree nitrogen status and leaf canopy position influence postharvest nitrogen accumulation and efflux from pear leaves. J Am Soc Hortic Sci 115:934-7.

[SAS] SAS Institute. 1989-2007. JMP Version 7. Cary, NC.

[USDA ERS] US Department of Agriculture Economic Research Service. 2009. California Fact Sheet. www. ers.usda.gov/StateFacts/CA.HTM\#TCEC.

Veltholf GL, Oudendag D, Witzke HP, et al. 2009 Integrated assessment of nitrogen losses from agriculture in EU-27 using MITERRA-EUROPE. J Environ Qual $38: 402-17$

Vitousek PM, Aber JD, Howarth RW, et al. 1997. Human alteration of the global nitrogen cycle: Sources and consequences. Ecol Appl 7(3):737-50

Weinbaum SA, Broadbent FE, Wicke W, Muraoka T. 1980. Nitrogen timing study. Years of Discovery (1972-2003). Almond Board of California, Modesto, CA. p 288.

Weinbaum SA, Carlson RM, Brown PH, et al. 1990 Optimization of nitrogen use. Years of Discovery (1972-2003). Almond Board of California, Modesto, CA. p 289-90. 